\title{
Evolutionary tradeoffs among nutrient acquisition, cell size, and grazing defense in marine phytoplankton promote ecosystem stability
}

\author{
W. G. Sunda*, D. R. Hardison \\ National Ocean Service, NOAA, 101 Pivers Island Road, Beaufort, North Carolina 28516, USA
}

\begin{abstract}
To survive, an algal species must maximize its reproduction rate via efficient nutrient acquisition and assimilation while minimizing rates of mortality from grazing or other sources. In a survey of 11 well studied marine algal species (including 3 racial variants of a single species, Emiliania huxleyi) in ammonium-limited cyclostat cultures, we observed variations in ammonium uptake rates and associated growth rates, which were linked to cell size and, apparently, also to grazing defense. The 5 largest species (10-12 $\mu \mathrm{m}$ cell diameter) had similar low ammonium uptake rates and associated ammonium-limited growth rates owing to diffusion limitation of uptake. Diffusive flux per unit of cell volume decreases with the inverse square of the cell diameter; hence, cells can minimize diffusion limitation and increase nutrient uptake by becoming smaller. However, this comes at the cost of higher susceptibility to grazing mortality. The 7 smallest isolates (2.7-4.6 $\mu \mathrm{m}$ diameter) had higher rates of ammonium uptake and growth as predicted from theory, but there was considerable variation for similarly sized cells. All 4 of the small algal species or isolates that are known to be poorly grazed or poorly assimilated by grazers had unusually low ammonium uptake rates and associated growth rates for their size, which we hypothesize to be due to the high cost of grazing defense. The results suggest the existence of evolutionary tradeoffs between large cell size and grazing defenses (which decrease grazing mortality) and small size and minimal defenses (which promote growth and reproduction). Such tradeoffs could increase the species diversity of algal communities, which in turn promotes ecosystem stability.
\end{abstract}

KEY WORDS: Ammonium - Phytoplankton · Nitrogen uptake · Growth rate - Grazing defense · Cell size $\cdot$ Evolutionary tradeoffs

\section{INTRODUCTION}

Marine microalgal communities comprise the base of the ocean's food web and are responsible for $\sim 40 \%$ of the earth's photosynthesis. There has been much progress in recent years in predicting overall phytoplankton productivity and biomass in marine waters and their impact on ocean carbon and nutrient cycles (Fung et al. 2000). However, we have very limited ability to predict the differential changes in the species composition of phytoplankton communities, largely due to a lack of understanding of the factors that control competition among species. Such species changes affect climate by controlling biogenic calcification
(Dymond \& Lyle 1985) and the transport of biogenic carbon to the deep sea (Martin \& Fitzwater 1988), and by controlling the release of dimethylsulfide (DMS), which provides a major source of cloud nucleation aerosols in the atmosphere (Charlson et al. 1987, Keller et al. 1989). An understanding of factors regulating algal competition and population shifts is also critical to predicting blooms of certain toxic or ecosystem disruptive algal species (Sunda et al. 2006). Such blooms have occurred with increasing frequency in recent decades, but the reasons for the dominance of specific harmful bloom species remain obscure (Cloern 2001).

To predict population changes, we must understand the factors that regulate competition among algal spe- 
cies. To survive or increase in numbers, a species must maintain an adequate net reproductive rate $\left(R_{\mathrm{n}}\right)$, which equals its specific reproductive rate $(R$, offspring per individual per unit time) minus its specific mortality rate $(m)$ :

$$
R_{\mathrm{n}}=R-m
$$

Phytoplankton reproduce largely by asexual cell division; consequently, specific rates of growth $(\mu)$ and reproduction tend to be equal. Sources of mortality include grazing by planktivores, and attack by viruses and parasitoids (e.g. bacteria) (Hamm \& Smetacek 2007, Strom 2008). However, grazing is by far the dominant source of mortality (Calbet \& Landry 2004); thus, Eq. (1) can be recast as:

$$
R_{\mathrm{n}}=R-m \sim \mu-g
$$

where $g$ is the specific grazing rate. To survive, an algal species must strive to maximize $\mu$ through efficient resource acquisition and utilization, and minimize $g$ by using grazing defense mechanisms or adopting a large cell geometry. Most of the historical focus among marine phytoplankton ecologists has been on the regulation of specific growth rate $(\mu)$ by nutrients, light and physical factors (temperature and mixing), with far less focus on the mechanisms species use to minimize grazing losses (Hamm \& Smetacek 2007, Strom 2008). Even less attention has been paid to the potential tradeoffs species face in optimizing growth while minimizing grazing losses, which is a fundamental tenet in terrestrial plant ecology (Coley et al. 1985, Herms \& Mattson 1992). A notable exception is the effect of decreased cell size, which simultaneously increases nutrient acquisition rates and grazing mortality rates (Thingstad \& Sakshaug 1990, Kiørboe 1993). But even here, the effect of cell size on uptake has been quantified for only a few species and a few nutrients, notably iron (Sunda \& Huntsman 1995a, Sunda \& Huntsman 1997) (7 species examined) and ammonium (Sunda \& Hardison 2007) (4 species at a single temperature).

In studying algal adaptation to nutrient limitation, it is important to choose a nutrient that is frequently limiting in the natural environment. Nitrogen is the primary limiting nutrient in coastal waters and stratified ocean waters (Ryther \& Dunstan 1971, Moore et al. 2008); thus, nitrogen $(\mathrm{N})$ uptake and utilization are critical factors regulating the competitive success of marine algal species. Among the $\mathrm{N}$ species (ammonium, nitrate, nitrite, urea, and various other organic $\mathrm{N}$ species), ammonium is the preferred $\mathrm{N}$ source, as most other chemical species (with the exception of amino acids) must first be converted to $\mathrm{NH}_{4}{ }^{+}$before they are assimilated into proteins and other $\mathrm{N}$-containing biomolecules. This ammonium conversion entails the investment of additional energy (ATP), enzymatic machinery, or photosynthetic reducing equivalents (NADPH); thus, ammonium use is energetically more efficient than utilization of most other $\mathrm{N}$ species. Consequently, $\mathrm{NH}_{4}{ }^{+}$is frequently the primary limiting inorganic $\mathrm{N}$ species in $\mathrm{N}$-limited marine waters (Harrison et al. 1996), and it has almost certainly influenced the adaptive strategies of phytoplankton.

In investigating differences in nutrient uptake capabilities among species, one must pay strict attention to variations in cell size because of the important influence of size on nutrient uptake rates. Increasing size decreases uptake rates of ammonium and other nutrients by decreasing rates of nutrient diffusion to the cell surface per unit of cell volume and by decreasing cell surface to volume ratios (Kiørboe 1993, Sunda \& Huntsman 1997, Raven 1999).

To investigate the intrinsic linkages among size, nutrient assimilation, reproduction rate, and grazing defense, we compared the relationships among cell size, ammonium concentration $\left[\mathrm{NH}_{4}{ }^{+}\right], \mathrm{N}$ uptake rate per unit of cell volume or carbon, cellular nitrogen: carbon (N:C) ratio, and specific growth rate for 13 marine algal isolates in $\mathrm{NH}_{4}{ }^{+}$-limited cyclostat cultures and nutrient-sufficient batch cultures. The isolates ranged in diameter from 2.7 to $12 \mu \mathrm{m}$ and represented 7 marine algal groups, a range of maximum growth rates and growth adaptation to low $\mathrm{NH}_{4}{ }^{+}$levels, and species or strains with varying grazing susceptibilities (see Table 1). The species included the small (4 to $6 \mu \mathrm{m}$ diameter) brown tide species Aureoumbra lagunensis, which has formed massive ecosystem disruptive blooms in Laguna Madre, Texas since 1990 (Buskey et al. 2001), and the small ( 3 $\mu \mathrm{m})$ green tide species Nannochloropsis gaditana and Nannochloris atomus, which formed similar harmful blooms in the coastal bays of southern Long Island, New York in the 1950s (Ryther 1989). The strains of $N$. atomus and $A$. lagunensis that we used in the present study were isolated from these blooms (see Table 1). Blooms of the green tide and brown tide species are believed to be partly linked to their substantial grazing deterrence capabilities and resultant low rates of grazing mortality (Sunda et al. 2006). To further investigate possible linkages between ammonium assimilation and grazing defense capabilities, we examined 3 clones of the coccolithophore Emiliania huxleyi whose grazing susceptibilities have been well documented in previous investigations. The coastal clones (CCMP 370 and 374) were reported to be well grazed by a variety of microzooplankton, while the oceanic clone from the Sargasso Sea (CCMP 373) was avoided or poorly grazed by the same zooplankton (Wolfe et al. 1997, Strom et al. 2003). 


\section{MATERIALS AND METHODS}

Culture experiments. Experiments were conducted at $20^{\circ} \mathrm{C}$ with 13 phytoplankton isolates (Table 1) that were obtained as axenic cultures from the Center for the Culture of Marine Phytoplankton (CCMP), Booth Bay Harbor, Maine, USA. The algae were grown in $\mathrm{NH}_{4}{ }^{+}$-limited cyclostat cultures and nutrientsufficient semi-continuous batch cultures using previously described procedures (Sunda \& Hardison 2007). Data were collected for the relationships among $\mathrm{NH}_{4}{ }^{+}$concentration; cellular $\mathrm{N}, \mathrm{C}$, and total volume; specific growth rate; average volume per cell; and cellular $\mathrm{NH}_{4}{ }^{+}$uptake rate using previously described analytical methods (Sunda \& Hardison 2007). The cyclostat culture media consisted of filtered Gulf Stream

Table 1. Experimental species and clones. CCMP: Center for the Culture of Marine Phytoplankton

\begin{tabular}{|c|c|c|c|}
\hline $\begin{array}{l}\text { Algal group } \\
\text { Species }\end{array}$ & $\begin{array}{l}\text { CCMP } \\
\text { clone }\end{array}$ & Isolation location & $\begin{array}{c}\text { Year } \\
\text { isolated }\end{array}$ \\
\hline \multicolumn{4}{|l|}{ Diatom } \\
\hline $\begin{array}{c}\text { Thalassiosira } \\
\text { weissflogii }\end{array}$ & 1336 & $\begin{array}{l}\text { Gardiners Island, Long } \\
\text { Island, NY, USA }\end{array}$ & 1956 \\
\hline $\begin{array}{l}\text { Cyclotella } \\
\text { cryptica }\end{array}$ & 333 & $\begin{array}{l}\text { Oyster Pond, Martha's } \\
\text { Vineyard, MA, USA }\end{array}$ & 1956 \\
\hline $\begin{array}{l}\text { Thalassiosira } \\
\text { pseudonana }\end{array}$ & 1335 & $\begin{array}{l}\text { Moriches Bay, Long } \\
\text { Island, NY, USA }\end{array}$ & 1958 \\
\hline \multicolumn{4}{|l|}{ Dinoflagellate } \\
\hline $\begin{array}{l}\text { Prorocentrum } \\
\text { mimimum }\end{array}$ & 1329 & $\begin{array}{l}\text { Great South Bay, Long } \\
\text { Island, NY, USA }\end{array}$ & 1958 \\
\hline $\begin{array}{l}\text { Amphidinium } \\
\text { carterae }\end{array}$ & 1314 & $\begin{array}{c}\text { Great Pond, Falmouth, } \\
\text { MA, USA }\end{array}$ & 1954 \\
\hline $\begin{array}{l}\text { Chryptophyte } \\
\text { Rhodomonas } \\
\text { salina }\end{array}$ & 1319 & Milford, CT, USA & 1956 \\
\hline \multicolumn{4}{|l|}{ Coccolithophore } \\
\hline $\begin{array}{l}\text { Pleurochrysis } \\
\text { carterae }\end{array}$ & 645 & $\begin{array}{l}\text { Woods Hole, } \\
\text { MA, USA }\end{array}$ & 1958 \\
\hline \multirow{3}{*}{$\begin{array}{l}\text { Emiliania } \\
\text { huxleyi }\end{array}$} & 374 & Gulf of Maine, USA & 1990 \\
\hline & 370 & Oslo Fjord, Norway & 1959 \\
\hline & 373 & $\begin{array}{c}\text { Sargasso Sea } \\
\left(32.2^{\circ} \mathrm{N}, 65.5^{\circ} \mathrm{W}\right)\end{array}$ & 1960 \\
\hline \multicolumn{4}{|l|}{ Pelagophyte } \\
\hline $\begin{array}{l}\text { Aureoumbra } \\
\text { lagunensis }\end{array}$ & 1509 & $\begin{array}{c}\text { Laguna Madre, TX, } \\
\text { USA }\end{array}$ & 1992 \\
\hline \multicolumn{4}{|l|}{ Trebouxiophyte } \\
\hline $\begin{array}{l}\text { Nannochloris } \\
\text { atomus }\end{array}$ & 509 & $\begin{array}{l}\text { Great South Bay, Long } \\
\text { Island, NY, USA }\end{array}$ & 1954 \\
\hline \multicolumn{4}{|l|}{ Eustigmatophyte } \\
\hline $\begin{array}{l}\text { Nannochloropsis } \\
\text { gaditana }\end{array}$ & 526 & $\begin{array}{c}\text { Lagune de Oualidia, } \\
\text { Morocco }\end{array}$ & 1985 \\
\hline
\end{tabular}

seawater (36 psu salinity) containing $12 \mu \mathrm{M} \mathrm{NH}{ }_{4} \mathrm{Cl}$, $2 \mu \mathrm{M} \mathrm{NaH} \mathrm{PO}_{4}, 40 \mu \mathrm{M} \mathrm{Na} \mathrm{SiO}_{3}, 10 \mathrm{nM} \mathrm{Na} \mathrm{SeO}_{3}$, vitamins, and an EDTA-trace metal buffer (Sunda \& Hardison 2007). The same medium was used for nutrient-sufficient semi-continuous cultures, but with $\mathrm{NH}_{4} \mathrm{Cl}$ being increased to $32 \mu \mathrm{M}$. Light was provided at an intensity of $100 \mu \mathrm{mol}$ quanta $\mathrm{m}^{-2} \mathrm{~s}^{-1}$ from fluorescent bulbs (Vita-Lite) on a 14:10 h light:dark cycle. Much of the data for 4 of the species (Thalassiosira pseudonana, T. weissflogii, A. lagunensis, and Nannochloris atomus) was taken from Sunda \& Hardison (2007) and Sunda et al. (2009). All data for the other 9 isolates and for the 2 lowest N-limited specific growth rates for $N$. atomus are newly reported here. Cellular $\mathrm{N}: \mathrm{C}$ ratios and net $\mathrm{N}$ uptake rates normalized to cell carbon in all species (except T. pseudonana and T. weissflogii) are also newly reported here, as are absolute ammonium uptake rates for all species.

$\mathrm{N}$ and $\mathrm{C}$ data were measured with a Costech $\mathrm{C} / \mathrm{N}$ analyzer after fuming with $\mathrm{HCl}$ to remove inorganic carbon (Sunda \& Hardison 2007). All samples were taken in the middle of the light period, and were analyzed in triplicate, except for cellular $\mathrm{N}$ and $\mathrm{C}$, which were analyzed in duplicate. Cellular $\mathrm{N}$ per unit of cell volume was determined by dividing the total cell $\mathrm{N}$ by the total cellular volume, which was measured with a Coulter Counter (Sunda \& Hardison 2007). Absolute cellular $\mathrm{N}$ uptake rates were computed by dividing the rate of cellular ammonium uptake in the culture (mol N ${ }^{-1}$ culture $\mathrm{d}^{-1}$ ) by the total cellular volume (l cell volume $\mathrm{l}^{-1}$ culture). The rate of cellular ammonium uptake equals the ammonium concentration in the inflowing medium minus the residual concentration in the culture multiplied by the culture dilution rate, which is the specific rate of medium addition.

Net uptake rate per unit of cell volume was computed by multiplying the cellular $\mathrm{N}$ to volume ratio by the culture dilution rate, while the net uptake rate per unit of cell carbon was computed by multiplying the cellular $\mathrm{N}: \mathrm{C}$ ratio by the dilution rate. The dilution rate equals the specific growth rate of the algae at steady state. The net $\mathrm{N}$ uptake rate equals the cellular uptake rate minus the rate of cellular loss due to leakage of organic solutes across the cell's outer membrane or intentional secretion of $\mathrm{N}$-containing compounds. Thus, it is often lower than the uptake rate.

Diffusion limitation of uptake and cell surface ammonium concentrations. As shown previously (Sunda \& Hardison 2007), the rate of ammonium uptake by algal cells can be limited by the rate of ammonium diffusion to the cell surface, which for a spherical cell is given by the equation: 


$$
\rho_{\mathrm{CV}}=3 D\left(\left[\mathrm{NH}_{4}{ }^{+}\right]-\left[\mathrm{NH}_{4}{ }^{+}\right]_{\mathrm{S}}\right) / r^{2}
$$

where $\rho_{\mathrm{CV}}$ is the diffusion rate per unit of cell volume, $\left[\mathrm{NH}_{4}{ }^{+}\right]$and $\left[\mathrm{NH}_{4}{ }^{+}\right]_{\mathrm{S}}$ are the $\mathrm{NH}_{4}{ }^{+}$concentrations in the bulk seawater and at the cell surface, respectively, and $\left[\mathrm{NH}_{4}{ }^{+}\right]-\left[\mathrm{NH}_{4}{ }^{+}\right]_{\mathrm{S}}$ is the concentration gradient between the bulk medium and the cell surface. $D$ is the ammonium diffusion coefficient, which has a value of $17.6 \times 10^{-6} \mathrm{~cm}^{2} \mathrm{~s}^{-1}$ in seawater at $20^{\circ} \mathrm{C}$ (Sunda \& Hardison 2007). $r$ is the cell radius, which is computed from the average measured volume per cell and the relation between the volume and radius of a sphere $(V=$ $\left.4 \pi r^{3} / 3\right)$, assuming a hypothetical spherical cell geometry. Based on Eq. (3), the limiting maximum diffusion rate $\left(\rho_{\mathrm{CV}(\max )}\right)$, at which the surface concentration is reduced to 0 , is given by:

$$
\rho_{\mathrm{CV}(\max )}=3 D\left[\mathrm{NH}_{4}{ }^{+}\right] / r^{2}
$$

The uptake of ammonium is ultimately dependent on the surface concentration, which is decreased from the bulk concentration under diffusion limitation. For a spherical cell, the surface ammonium is computed from the equation:

$$
\left[\mathrm{NH}_{4}{ }^{+}\right]_{\mathrm{S}}=\left[\mathrm{NH}_{4}{ }^{+}\right]\left(1-V_{\mathrm{CV}} / \rho_{\mathrm{CV}(\max )}\right)
$$

where $V_{\mathrm{CV}}$ is the ammonium uptake rate normalized to cell volume.

In the present work, we plotted the cellular uptake rate per unit of cell volume as a function of the measured ammonium concentration. In addition, we computed the uptake rate per unit of cell surface area, and plotted this as a function of the surface ammonium concentration as computed from Eq. (5). To compute uptake rate per unit of cell surface, we again assumed a spherical cell geometry, and divided the volume normalized uptake rate by the surface to volume ratio of a sphere $(3 / r)$.

The above equations assume a spherical cell geometry. This assumption should apply exactly to the 7 isolates at the bottom of Table 1 that all have spherical shapes (Pleurochrysis carterae, Emiliania huxleyi (clones CCMP 373, 370, and 374), Aureoumbra lagunensis, Nannochloris atomus, and Nannochloropsis gaditana). Cells of the 3 centric diatoms (Thalassiosira pseudonana, T. weissflogii, and Cyclotella cryptica) are equidimensional rounded cylinders, while those of the dinoflagellates Prorocentrum minimum and Amphidinium carterae and the cryptomonad Rhodomonas salina have spheroidal shapes that deviate only slightly from spheres. Thus, the assumption of a spherical geometry for these species should result in only minor errors since the aspect ratios for these cells are near unity (Pasciak \& Gavis 1974).

\section{RESULTS}

\section{Growth rate data}

Relationships between specific growth rate and ammonium concentration show a clear trend among species in their ammonium requirement for maximum growth rate (Fig. 1). Phytoplankton, like terrestrial plants, can be roughly divided into low-resource (K-selected) and high-resource adapted (r-selected) species, although a continuum undoubtedly exists (Kilham \& Hecky 1988, Sommer 1989). The 3 diatoms (Thalassiosira pseudonana, T. weissflogii, and Cyclotella cryptica) and the coastal coccolithophore (Pleurochrysis carterae) appear to be high-nutrient, r-selected species, based on their high $\mathrm{NH}_{4}{ }^{+}$requirements for maximum growth rate (80 to $100 \mathrm{nM}$; Fig. 1A). This result agrees with the noted dominance of diatoms in nutrient-rich waters (Kilham \& Hecky 1988). Two other species (the cryptophyte Rhodomonas salina and the dinoflagellate Prorocentrum minimum) had maximum growth rate requirements of $\sim 50$ to $60 \mathrm{nM}$ and thus appear to be intermediate in the $\mathrm{r}-\mathrm{K}$ continuum (Fig. 1A). All 7 of the remaining isolates appear to be K-selected species based on their low ammonium requirement ( 25 to $40 \mathrm{nM}$ ) for maximum growth rate (Fig. 1).

A second important feature of the curves for specific growth rate vs. ammonium concentration is the low growth rate of all 6 larger species ( 7 to $12 \mu \mathrm{m}$ mean diameter) relative to that of the small diatom Thalassiosira pseudonana (4.6 $\mu \mathrm{m}$ diameter) under both ammonium limitation and nutrient sufficiency (Fig. 1A). Within this group, there was a general inverse trend with cell size. The largest species (the dinoflagellate Prorocentrum minimum, $12.3 \mu \mathrm{m}$ diameter) showed the lowest maximum growth rate and lowest $\mathrm{N}$-limited growth rates at given ammonium concentrations. The 4 slightly smaller species (10 to $11 \mu \mathrm{m}$ diameter, the diatoms Thalassiosira weissflogii and Cyclotella cryptica, the coccolithophore Pleurochrysis carterae, and the dinoflagellate Amphidinium carterae) showed consistent, slightly higher N-limited growth rates, and higher maximum growth rates (Fig. 1A). The cryptophyte Rhodomonas salina (7 $\mu \mathrm{m}$ diameter), showed the highest ammonium-limited growth rates at given ammonium concentrations among the larger species.

The small diatom Thalassiosira pseudonana (4.6 $\mu \mathrm{m}$ diameter) exhibited the highest growth rates among all of the isolates at both limiting and nonlimiting ammonium concentrations (Fig. 1B). However, there was a large range in ammonium-limited growth rates and maximum growth rates among the 7 smallest species or isolates (2.7 to $4.6 \mu \mathrm{m}$ diameter) that did not appear 


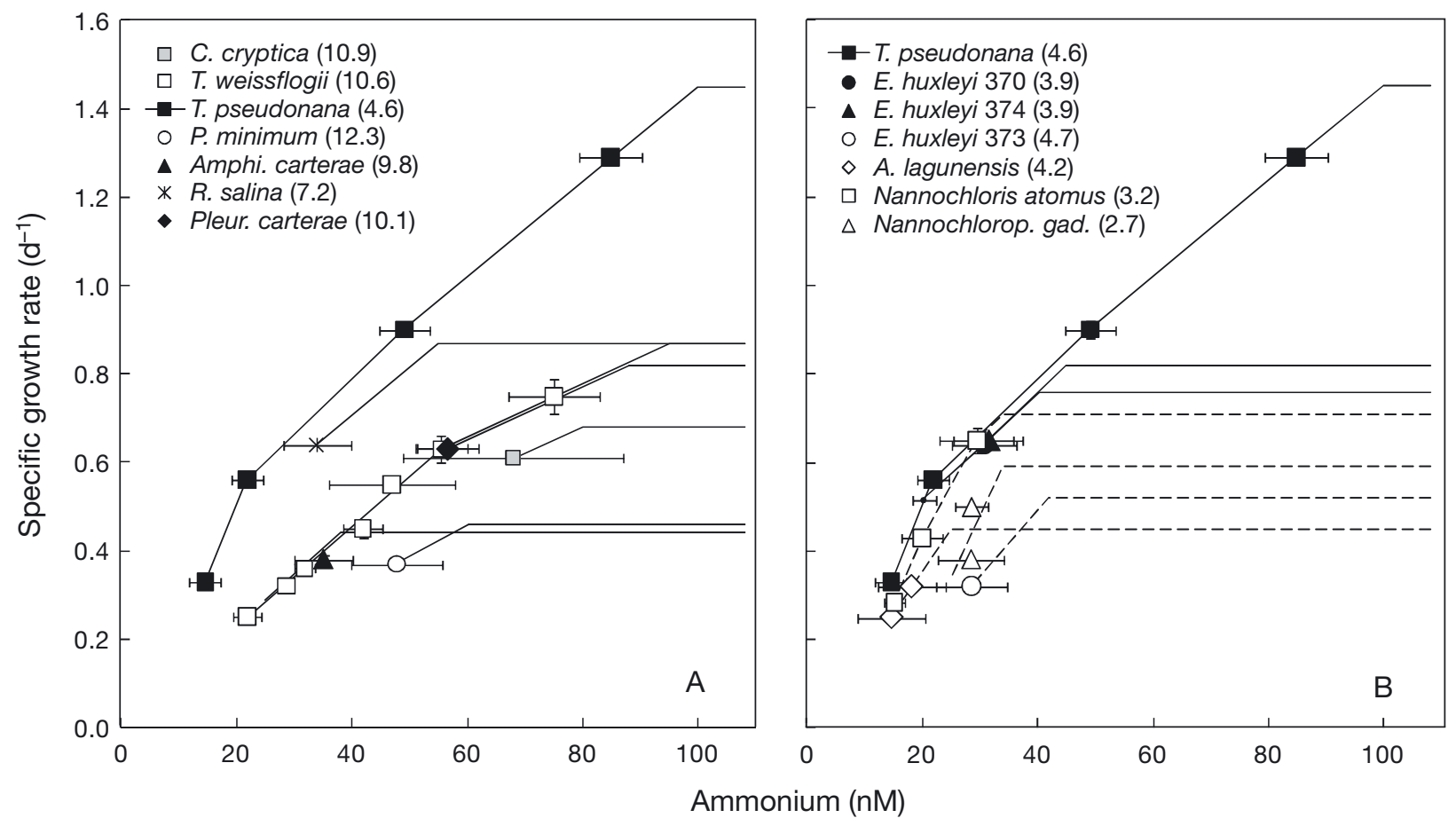

Fig. 1. Relationships between specific growth rate and $\mathrm{NH}_{4}{ }^{+}$concentration $( \pm \mathrm{SD}$, based on Table 2$)$ for 13 algal strains in nitrogenlimited cyclostats. Data for Thalassiosira pseudonana are plotted in both panels for comparison. Data for T. pseudonana, T. weissflogii, and Aureoumbra lagunensis, and a portion of the data for Nannochloris atomus are taken from Sunda \& Hardison (2007). The rest of the data is newly reported here. Horizontal lines: maximum rates at growth-saturating $\mathrm{NH}_{4}{ }^{+}$. Mean equivalent spherical cell diameters $(\mu \mathrm{m})$ under N-limitation are given in parentheses for each species. Dashed lines indicate the 4 small species with the most robust grazing defences. Vertical error bars: SEs of slopes of linear regressions of ln cell volume vs. time (see ‘Materials and methods'). Most error bars are not visible because they are smaller than the data points. For full species names see Table 1

to be linked to cell size. The 2 small coastal isolates of Emiliania huxleyi (CCMP 374 and 370, 3.9 to $4.0 \mu \mathrm{m}$ ) had N-limited growth rates at given ammonium concentrations that equaled those of $T$. pseudonana, but their maximum growth rates were considerably lower. The 4 remaining small isolates had the lowest maximum growth rates $\left(0.45\right.$ to $\left.0.71 \mathrm{~d}^{-1}\right)$ of all the small-celled algal species or strains, and all exhibited the lowest growth rates under ammonium limitation (Fig. 1B). These isolates included the brown tide pelagophyte Aureoumbra lagunensis, the green tide eustigmatophyte Nannochloropsis gaditana, the green tide trebouxiophyte Nannochloris atomus (3.2 $\mathrm{mm}$ diameter), and the oceanic isolate of the coccolithophore Emiliania huxleyi (CCMP 373). These species or isolates have one thing in common; they all have robust grazing deterrent mechanisms involving toxicity, indigestibility, or interference with grazing mechanisms (Wolfe et al. 1997, Strom et al. 2003, Sunda et al. 2006). These antigrazing defenses have enabled N. gaditana, N. atomus, and A. lagunensis to form large, persistent, ecosystem-disruptive algal blooms (Ryther 1989, Buskey et al. 2001, Sunda et al. 2006).

\section{Ammonium uptake rates}

Cellular $\mathrm{N}$ concentrations (in mol $\mathrm{l}^{-1}$ medium) were often less than the difference in concentration between inflowing ammonium $(12 \mu \mathrm{M})$ and the small residual ammonium in the cyclostats $(\leq 0.085 \mu \mathrm{M})$. Consequently, the computed net uptake rates were often lower than the absolute uptake rates, likely because of the excretion or leakage of organic $\mathrm{N}$ compounds (Table 2). In our study, the apparent release of organic $\mathrm{N}$ did not occur for the large dinoflagellates (10 to $12 \mu \mathrm{m}$ diameter) and for the large diatoms Cyclotella cryptica and Thalassiosira weissflogii (10 to $11 \mu \mathrm{m}$ diameter), provided that growth rate was not $\mathrm{N}$-limited by $>60 \%$ (Table 2). However, in the 2 most severely Nlimited $T$. weissflogii cultures, the net uptake was only 79 and $69 \%$, respectively, of the computed absolute uptake rate (Table 2, Fig. 2). The small diatom Thalassiosira pseudonana showed a similar trend. It exhibited no discrepancy between net and absolute uptake rates at an N-limited specific growth rate of $1.29 \mathrm{~d}^{-1}$ (89\% of the nutrient-sufficient rate), but showed a net uptake rate that was only $57 \%$ of the absolute rate at the most severely $\mathrm{N}$-limited growth rate $\left(0.33 \mathrm{~d}^{-1}, 20 \%\right.$ of the 
Table 2. $\mathrm{NH}_{4}{ }^{+}$concentration, cell diameter, specific growth rate, absolute and net $\mathrm{NH}_{4}{ }^{+}$uptake rates normalized to cell volume and absolute uptake rate as a percentage of the maximum diffusion rate. Maximum limiting diffusion rates are based on absolute uptake rates. Data for ammonium concentration, cell diameter, specific growth rate and net ammonium uptake rate for T. pseudonana, T. weissflogii, A. lagunensis, and the 2 higher growth rates for N. atomus are from Sunda \& Hardison (2007). All other data are newly reported here

\begin{tabular}{|c|c|c|c|c|c|c|c|}
\hline Species & $\begin{array}{c}{\left[\mathrm{NH}_{4}^{+}\right]} \\
(\mathrm{nM})\end{array}$ & $\begin{array}{l}\text { Diameter } \\
(\mu \mathrm{m})\end{array}$ & $\begin{array}{l}\text { Growth } \\
\text { rate } \\
\left(\mathrm{d}^{-1}\right)\end{array}$ & $\begin{array}{l}\text { Absolute } \\
\text { uptake rate } \\
\left(\mathrm{mol} \mathrm{l}^{-1} \mathrm{~d}^{-1}\right)\end{array}$ & $\begin{array}{l}\text { Net uptake } \\
\text { rate } \\
\left(\mathrm{mol} \mathrm{l}^{-1} \mathrm{~d}^{-1}\right)\end{array}$ & $\begin{array}{l}\text { \% Maximum } \\
\text { diffusion } \\
\text { rate }\end{array}$ & $\mathrm{n}$ \\
\hline \multirow{8}{*}{$\begin{array}{c}\text { Thalassiosira } \\
\text { weissflogii }\end{array}$} & & $12.6 \pm 0.1^{\mathrm{a}}$ & $0.87 \pm 0.02^{\mathrm{a}}$ & & & & \\
\hline & $75.0 \pm 7.8$ & $10.1 \pm 0.0$ & $0.75 \pm 0.04$ & $1.04 \pm 0.06$ & $1.04 \pm 0.05$ & $78.5 \pm 11.1$ & 3 \\
\hline & $55.5 \pm 4.5$ & $10.3 \pm 0.0$ & $0.63 \pm 0.03$ & $0.68 \pm 0.00$ & $0.71 \pm 0.01$ & $78.6 \pm 10.1$ & 4 \\
\hline & $46.9 \pm 9.7$ & $11.0 \pm 0.0$ & $0.55 \pm 0.00$ & $0.53 \pm 0.00$ & $0.53 \pm 0.00$ & $77.0 \pm 14.4$ & 4 \\
\hline & $41.9 \pm 3.5$ & $11.1 \pm 0.1$ & $0.45 \pm 0.02$ & $0.39 \pm 0.02$ & $0.39 \pm 0.02$ & $63.1 \pm 5.4$ & 8 \\
\hline & $31.8 \pm 1.8$ & $11.2 \pm 0.0$ & $0.36 \pm 0.01$ & $0.31 \pm 0.02$ & $0.31 \pm 0.02$ & $67.0 \pm 5.4$ & 5 \\
\hline & $28.7 \pm 0.8$ & $10.1 \pm 0.1$ & $0.32 \pm 0.01$ & $0.43 \pm 0.03$ & $0.34 \pm 0.02$ & $84.0 \pm 7.4$ & 4 \\
\hline & $21.9 \pm 2.4$ & $10.1 \pm 0.0$ & $0.25 \pm 0.01$ & $0.29 \pm 0.01$ & $0.20 \pm 0.01$ & $74.7 \pm 9.2$ & 4 \\
\hline \multirow{2}{*}{$\begin{array}{l}\text { Cyclotella } \\
\text { cryptica }\end{array}$} & & $12.4 \pm 0.2^{\mathrm{a}}$ & $0.68 \pm 0.08^{\mathrm{a}}$ & & & & \\
\hline & $67.9 \pm 19.1$ & $10.9 \pm 0.0$ & $0.61 \pm 0.02$ & $0.68 \pm 0.12$ & $0.68 \pm 0.12$ & $66.7 \pm 6.3$ & 3 \\
\hline \multirow{5}{*}{$\begin{array}{l}\text { Thalassiosira } \\
\text { pseudonana }\end{array}$} & & $4.8 \pm 0.1^{\mathrm{a}}$ & $1.45^{\mathrm{a}}$ & & & & \\
\hline & $84.8 \pm 5.4$ & $4.7 \pm 0.0$ & $1.29 \pm 0.0$ & $2.62 \pm 0.02$ & $2.63 \pm 0.02$ & $36.6 \pm 2.4$ & 2 \\
\hline & $49.1 \pm 4.4$ & $4.6 \pm 0.0$ & $0.90 \pm 0.02$ & $2.08 \pm 0.10$ & $1.93 \pm 0.10$ & $49.4 \pm 2.6$ & 3 \\
\hline & $21.8 \pm 2.7$ & $4.4 \pm 0.1$ & $0.56 \pm 0.0$ & $0.98 \pm 0.09$ & $0.73 \pm 0.06$ & $47.2 \pm 3.6$ & 4 \\
\hline & $14.6 \pm 2.7$ & $4.3 \pm 0.1$ & $0.33 \pm 0.01$ & $0.97 \pm 0.13$ & $0.55 \pm 0.07$ & $68.1 \pm 13.3$ & 6 \\
\hline \multirow{2}{*}{$\begin{array}{l}\text { Prorocentrum } \\
\text { minimum }\end{array}$} & & $13.7 \pm 0.4^{\mathrm{a}}$ & $0.46 \pm 0.02^{\mathrm{a}}$ & & & & \\
\hline & $47.7 \pm 7.9$ & $12.3 \pm 0.1$ & $0.37 \pm 0.01$ & $0.44 \pm 0.02$ & $0.44 \pm 0.02$ & $77.4 \pm 11.0$ & 3 \\
\hline \multirow{2}{*}{$\begin{array}{l}\text { Amphidinium } \\
\text { carterae }\end{array}$} & & $11.1 \pm 0.3^{\mathrm{a}}$ & $0.44 \pm 0.01^{\mathrm{a}}$ & & & & \\
\hline & $35.1 \pm 5.0$ & $9.8 \pm 0.1$ & $0.39 \pm 0.01$ & $0.46 \pm 0.09$ & $0.46 \pm 0.09$ & $67.8 \pm 13.9$ & 4 \\
\hline \multirow{2}{*}{$\begin{array}{l}\text { Rhodomonas } \\
\text { salina }\end{array}$} & & $8.6 \pm 0.5^{\mathrm{a}}$ & $0.87 \pm 0.01^{\mathrm{a}}$ & & & & \\
\hline & $33.9 \pm 5.9$ & $7.2 \pm 0.1$ & $0.64 \pm 0.00$ & $2.14 \pm 0.14$ & $1.04 \pm 0.00$ & $184 \pm 29$ & 3 \\
\hline \multirow{2}{*}{$\begin{array}{l}\text { Pleurochrysis } \\
\text { carterae }\end{array}$} & & $11.3 \pm 0.4^{\mathrm{a}}$ & $0.82 \pm 0.03^{\mathrm{a}}$ & & & & \\
\hline & $56.6 \pm 5.3$ & $10.1 \pm 0.1$ & $0.63 \pm 0.02$ & $0.65 \pm 0.05$ & $0.33 \pm 0.01$ & $65.6 \pm 7.6$ & 4 \\
\hline \multirow{2}{*}{$\begin{array}{l}\text { Emiliania } \\
\text { huxleyi (374) }\end{array}$} & & $4.8 \pm 0.2^{\mathrm{a}}$ & $0.76 \pm 0.02^{\mathrm{a}}$ & & & & \\
\hline & $31.5 \pm 6.0$ & $3.9 \pm 0.1$ & $0.65 \pm 0.02$ & $1.25 \pm 0.34$ & $0.92 \pm 0.09$ & $34.3 \pm 15.2$ & 6 \\
\hline \multirow{3}{*}{$\begin{array}{l}\text { Emiliania } \\
\text { huxleyi (370) }\end{array}$} & & $4.8 \pm 0.1^{\mathrm{a}}$ & $0.82 \pm 0.01^{\mathrm{a}}$ & & & & \\
\hline & $30.7 \pm 5.2$ & $3.8 \pm 0.1$ & $0.64 \pm 0.03$ & $1.45 \pm 0.65$ & $0.97 \pm 0.07$ & $41.5 \pm 15.9$ & 5 \\
\hline & $20.3 \pm 2.1$ & $4.0 \pm 0.2$ & $0.52 \pm 0.01$ & $0.97 \pm 0.29$ & $0.67 \pm 0.03$ & $43.4 \pm 12.9$ & 2 \\
\hline \multirow{2}{*}{$\begin{array}{l}\text { Emiliania } \\
\text { huxleyi (373) }\end{array}$} & & $5.0 \pm 0.2^{\mathrm{a}}$ & $0.45 \pm 0.02^{\mathrm{a}}$ & & & & \\
\hline & $28.5 \pm 6.2$ & $4.7 \pm 0.1$ & $0.32 \pm 0.01$ & $0.44 \pm 0.08$ & $0.35 \pm 0.01$ & $19.1 \pm 4.3$ & 4 \\
\hline \multirow{3}{*}{$\begin{array}{l}\text { Aureoumbra } \\
\text { lagunensis }\end{array}$} & & $5.7 \pm 0.1^{\mathrm{a}}$ & $0.45 \pm 0.00^{\mathrm{a}}$ & & & & \\
\hline & $18.3 \pm 3.7$ & $4.2 \pm 0.1$ & $0.31 \pm 0.01$ & $0.44 \pm 0.01$ & $0.38 \pm 0.00$ & $24.2 \pm 4.6$ & 4 \\
\hline & $14.6 \pm 2.8$ & $4.1 \pm 0.1$ & $0.25 \pm 0.00$ & $0.31 \pm 0.06$ & $0.25 \pm 0.00$ & $20.0 \pm 4.5$ & 5 \\
\hline \multirow{4}{*}{$\begin{array}{l}\text { Nannochloris } \\
\text { atomus }\end{array}$} & & $3.5 \pm 0.1^{\mathrm{a}}$ & $0.71 \pm 0.01^{\mathrm{a}}$ & & & & \\
\hline & $29.4 \pm 6.4$ & $3.1 \pm 0.1$ & $0.65 \pm 0.03$ & $1.20 \pm 0.22$ & $1.10 \pm 0.10$ & $21.5 \pm 2.1$ & 6 \\
\hline & $20.0 \pm 3.6$ & $3.3 \pm 0.1$ & $0.43 \pm 0.00$ & $0.56 \pm 0.04$ & $0.56 \pm 0.00$ & $17.0 \pm 2.1$ & 3 \\
\hline & $15.2 \pm 1.7$ & $3.1 \pm 0.2$ & $0.28 \pm 0.00$ & $0.51 \pm 0.00$ & $0.26 \pm 0.00$ & $18.5 \pm 2.2$ & 2 \\
\hline \multirow{3}{*}{$\begin{array}{l}\text { Nannochloropsis } \\
\text { gaditana }\end{array}$} & & $2.7 \pm 0.1^{\mathrm{a}}$ & $0.59 \pm 0.01^{\mathrm{a}}$ & & & & \\
\hline & $28.5 \pm 2.9$ & $2.7 \pm 0.0$ & $0.50 \pm 0.02$ & $1.15 \pm 0.10$ & $0.74 \pm 0.03$ & $16.1 \pm 2.0$ & 3 \\
\hline & $28.4 \pm 5.7$ & $2.7 \pm 0.0$ & $0.38 \pm 0.00$ & $0.51 \pm 0.04$ & $0.49 \pm 0.00$ & $7.4 \pm 1.0$ & 3 \\
\hline
\end{tabular}

maximum rate). Because of these patterns, curves for absolute and net uptake rates vs. ammonium concentration had different slopes, and the curves converged at higher ammonium concentrations (Fig. 2).

Whether we examined absolute (Fig. 3) or net uptake rates (Fig. 4), the same general pattern as that observed for growth rate was observed among the species and isolates. The 5 largest species (10 to $12 \mu \mathrm{m}$ cell diameter) had consistently lower uptake rates compared to the small diatom Thalassiosira pseudonana at a given ammonium concentration (Figs. 3A \& 4A). Moreover, the 6 smallest isolates exhibited generally high, but 


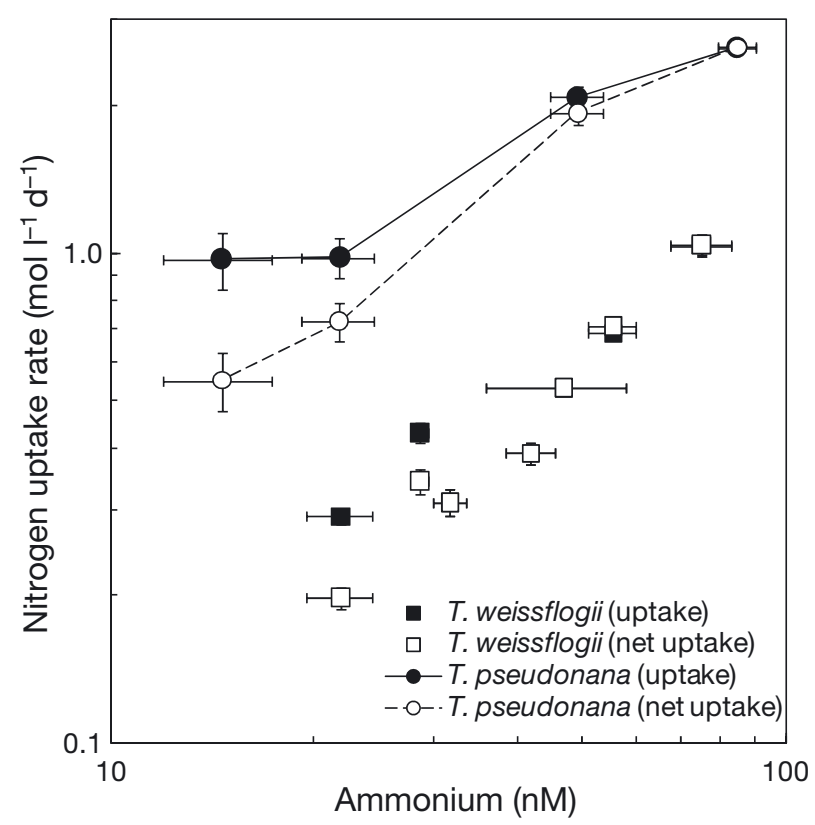

Fig. 2. Relationships between the absolute and net cellular nitrogen uptake rate (normalized per liter of cell volume) and ammonium concentration (note exponential scale on both axes). Net uptake rates for Thalassiosira pseudonana and T. weissflogii are taken from Sunda \& Hardison (2007), while absolute rates are newly reported here for the same experiments. For T. weissflogii, absolute and net uptake rates were equal at the 5 highest ammonium concentrations; consequently, only 1 data point is shown at each of these concentrations. Error bars: \pm SD variable ammonium uptake rates. Among these isolates, T. pseudonana and the 2 coastal Emiliania huxleyi clones (CCMP 370 and 374) showed consistently high uptake rates at a given ammonium level, while the 4 isolates with low ammonium-limited growth rates (Aureoumbra lagunensis, Nannochloropsis gaditana, Nannochloris atomus, and E. huxleyi (CCMP 373)) generally showed much lower uptake rates (Fig. 3B).

Thus, cell size appears to be an important factor regulating uptake rates, as is expected from theory based on surface to volume ratios and nutrient diffusion to the cell surface. To take into account the effect of cell size on these 2 factors, we computed the uptake rate per unit of cell surface and plotted this as a function of the cell surface ammonium concentration as computed from Eqs. (4) and (5) (see 'Materials and methods'). All but 5 species or isolates exhibited the same relationship between uptake rate per unit of cell surface and surface ammonium concentration (Fig. 5). One exception was Rhodomonas salina, where the uptake rate exceeded the maximum limiting diffusion rate (Table 2), making it impossible to compute the surface ammonium concentration. This difficulty may have been caused by the high motility of this species, which may have reduced the thickness of the cell's diffusive boundary layer and thereby increased the maximum diffusion rate (Kiørboe 1993); this factor is not accounted for in our theoretical calculations. The other exceptions were the 4 poorly

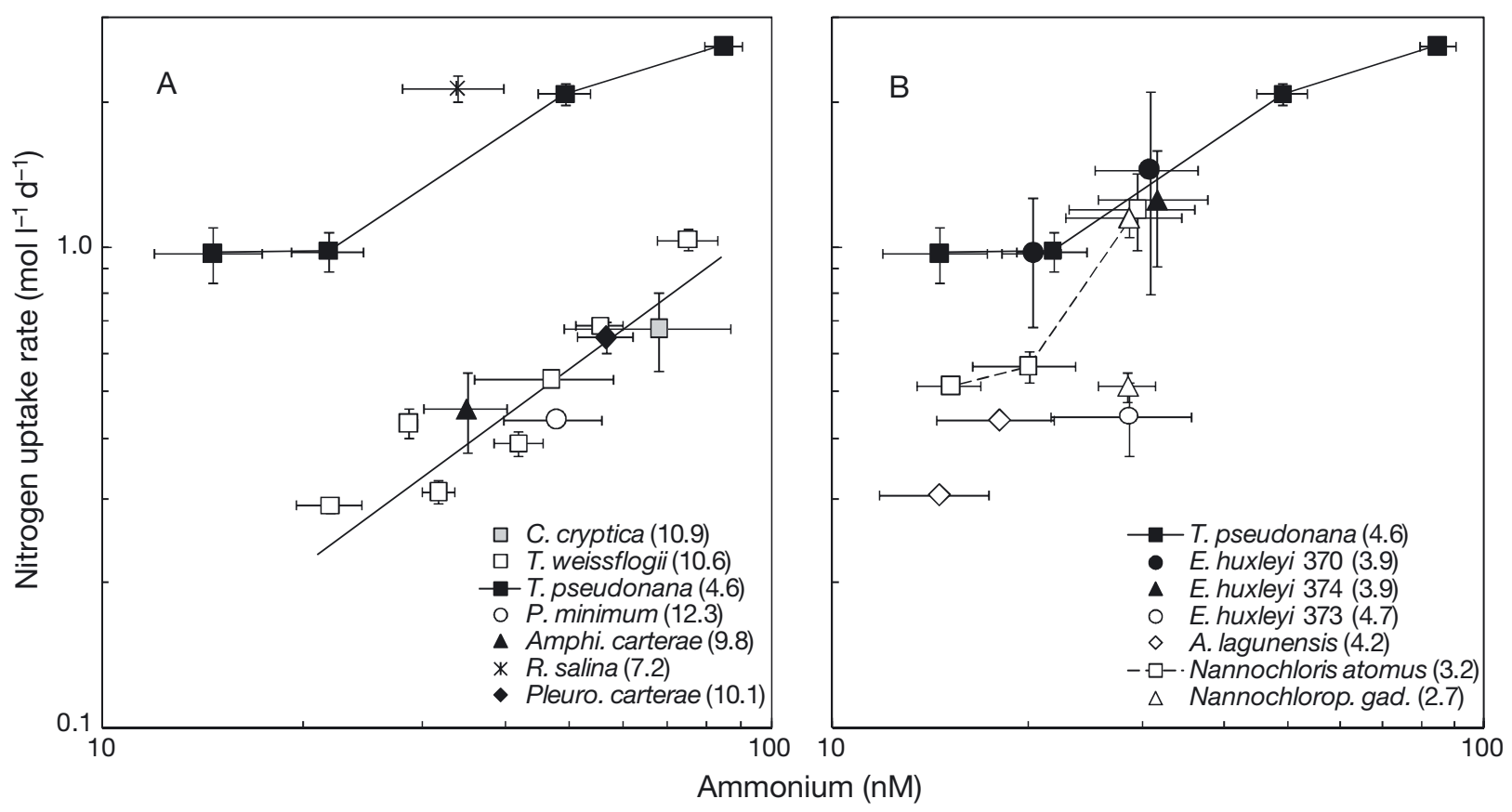

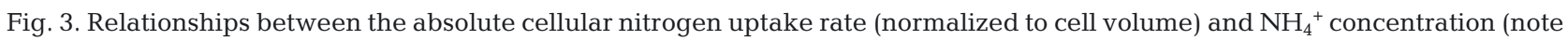
exponential scale on both axes). The CCMP clone numbers are given for the 3 Emiliania huxleyi strains. For full species names see Table 1. Error bars: \pm SD 
grazed/well defended species or isolates (Aureoumbra lagunensis, Nannochloropsis gaditana, Nannochloris atomus, and Emiliania huxleyi [CCMP 373]), which all

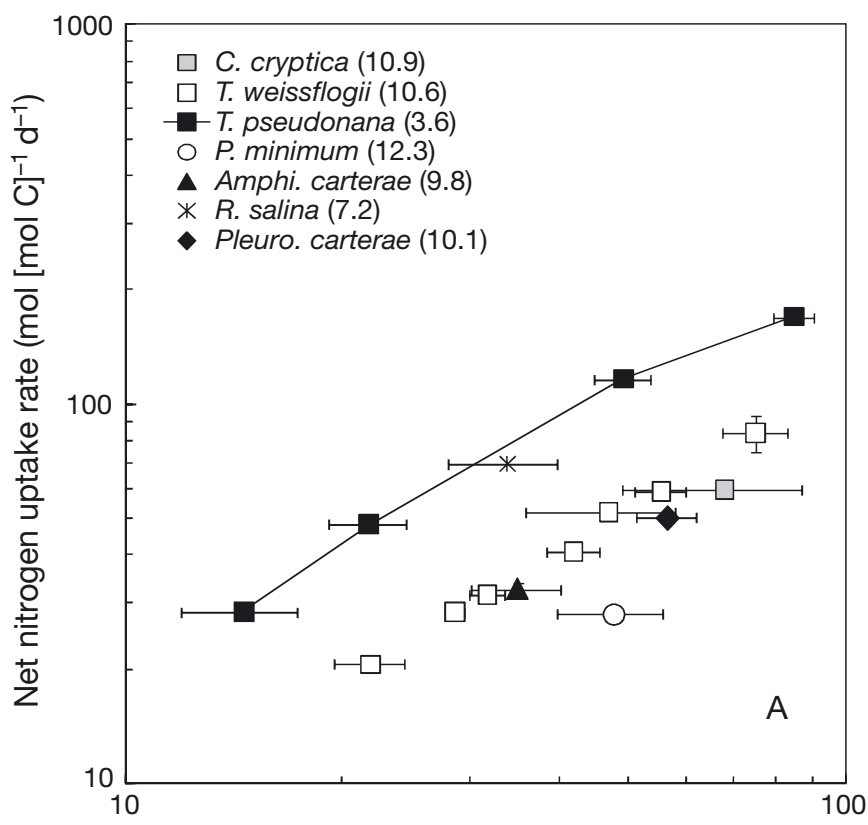

had uptake rates per unit of cell surface at a given surface ammonium concentration that were 20 to $40 \%$ of those of the other species (Fig. 5).

Ammonium (nM)

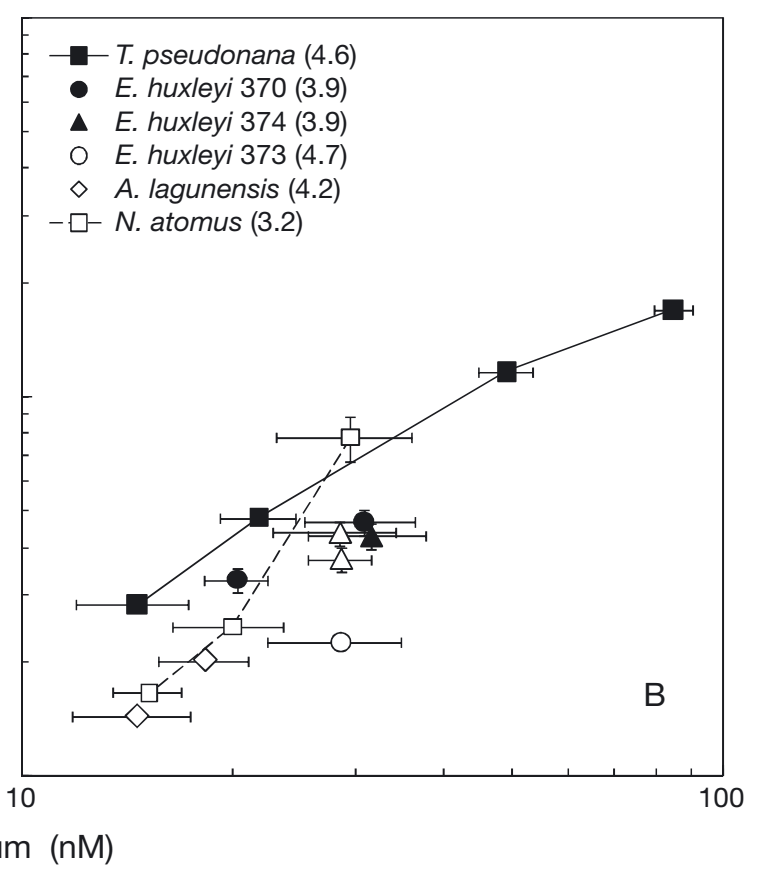

Fig. 4. Relationships between net cellular nitrogen uptake rate (normalized per mole of cell carbon) and ammonium concentration. Data for Thalassiosira pseudonana and T. weissflogii are taken from Sunda et al. (2009). The rest of the data is newly reported here. The CCMP clone numbers are given for the 3 Emiliania huxleyi strains. For full species names see Table 1.

\section{Error bars: $\pm \mathrm{SD}$}

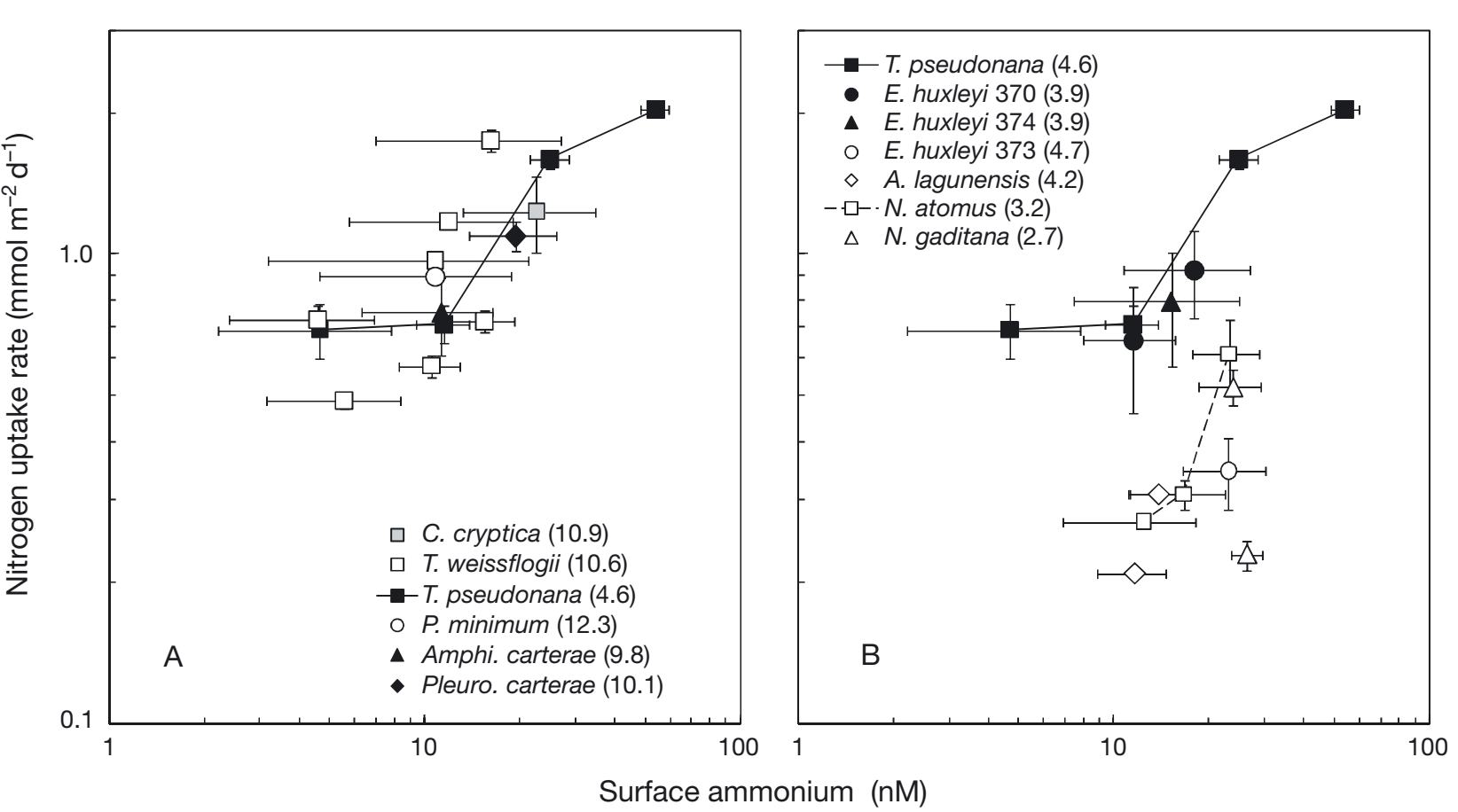

Fig. 5. Relationships between the absolute cellular nitrogen uptake rate (normalized to cell surface area) and $\mathrm{NH}_{4}^{+}$concentration at the cell surface computed from Eqs. (4) \& (5). The CCMP clone numbers are given for the 3 Emiliania huxleyi strains. Data for Thalassiosira pseudonana are plotted in both panels for comparison. For full species names see Table 1 . Error bars: \pm SD 


\section{Relationships between specific growth rate and cellular $\mathrm{N}: \mathrm{C}$ ratio}

The putative r-selected species all had high rates of ammonium uptake and growth for their size, while the $4 \mathrm{~K}$-selected species or isolates with robust grazing defenses all show just the opposite. These 2 groups also showed distinct patterns in relationships between specific growth rate and cellular $\mathrm{N}$ : C ratios (Fig. 6). At low growth rates $\left(\leq 0.5 \mathrm{~d}^{-1}\right)$, the 4 well defended, $\mathrm{K}$-selected species required a lower $\mathrm{N}$ : C ratio than the putative r-selected species to achieve a given growth rate, while the opposite was true at higher growth rates. Another indicator of this pattern is the $\mathrm{N}$ use efficiency (the net moles of $\mathrm{C}$ fixed mole $^{-1}$ cell $\mathrm{N} \mathrm{d}^{-1}$ ), which equals the specific growth rate divided by the cellular $\mathrm{N}$ :C ratio. At growth rates $\leq 0.5 \mathrm{~d}^{-1}$, the mean $\mathrm{N}$ use efficiency of the 4 well defended, K-selected species was $5.6 \pm 1.2 \mathrm{~mol} \mathrm{C}(\mathrm{mol} \mathrm{N})^{-1} \mathrm{~d}^{-1}( \pm \mathrm{SD})$ while that for $2 \mathrm{r}$-selected diatoms (Thalassiosira pseudonana and T. weissflogii) was $\sim 40 \%$ lower $\left(3.5 \mathrm{~mol} \mathrm{C}(\mathrm{mol} \mathrm{N})^{-1}\right.$ $\left.\mathrm{d}^{-1}\right)$. In contrast, at high $\mathrm{N}$ : $\mathrm{C}$ ratios, $\left(\geq 100 \mathrm{mmol} \mathrm{mol}^{-1}\right)$, the mean $\mathrm{N}$ use efficiency of the r-selected species was $7.3 \pm 1.2 \mathrm{~mol} \mathrm{C}(\mathrm{mol} \mathrm{N})^{-1} \mathrm{~d}^{-1}$, which is $50 \%$ higher than that for the well defended, K-selected species.

Curve fits of the data to the Droop equation (Droop 1968) for the 2 groups of species also show the same pattern. The Droop equation is:

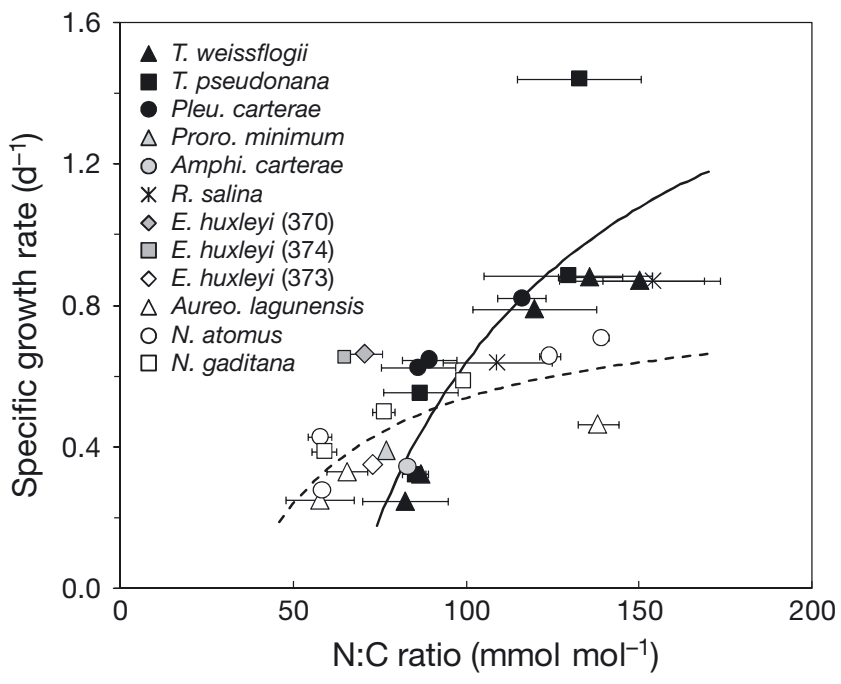

Fig. 6. Relationships between specific growth rate and cellular N:C molar ratio for all species except Cyclotella cryptica, for which N:C ratio data are not available. Solid curve: Droop equation fits for 3 putative r-selected species (Thalassiosira pseudonana, T. weissflogii, and Pleurochrysis carterae; filled symbols); dashed curve: Droop equation fits for the 4 poorly grazed, K-selected species and strains (Emiliania huxleyi [CCMP 373], Aureoumbra lagunensis, Nannochloris atomus, and Nannochloropsis gaditana) (open symbols). Error bars: \pm SD (vertical error bars are smaller than datapoints)

$$
\mu=\mu_{\max }^{\prime}\left(Q-Q_{\min }\right) / Q
$$

where $\mu$ is the specific growth rate, $Q$ is the cellular $\mathrm{N}$ quota (in our case the cellular N:C ratio) and $Q_{\min }$ is the minimum $\mathrm{N}: \mathrm{C}$ ratio at which growth rate is reduced to 0 . The term $\mu_{\text {max }}^{\prime}$ is a hypothetical maximum growth rate at infinite $Q$, and is essentially a fitting parameter for the equation. Nonlinear regression fits of the data to the Droop equation for the 2 groups of species yielded distinctly different curves, which crossed at an $\mathrm{N}$ : C ratio of $\sim 90 \mathrm{mmol} \mathrm{N}(\mathrm{mol} \mathrm{C})^{-1}$. The data fit for 3 putative r-selected species yielded a Droop equation with high values for $\mu_{\max }^{\prime}\left(1.95 \mathrm{~d}^{-1}\right)$ and $Q_{\min }$ $\left(67.2 \mathrm{mmol} \mathrm{mol}^{-1}\right)\left(\mathrm{R}^{2}=0.69\right)(\mathrm{N}: \mathrm{C}$ ratios for the 4 th r-selected species, Cyclotella cryptica, were not measured). In comparison, the regression fit for the 4 well defended, K-selected species yielded much lower values for $\mu_{\text {max }}^{\prime}\left(0.84 \mathrm{~d}^{-1}\right)$ and $Q_{\min }\left(35.7 \mathrm{mmol} \mathrm{mol}{ }^{-1}\right)\left(\mathrm{R}^{2}=\right.$ 0.70) (Fig. 6). The fact that the well defended, $\mathrm{K}$-selected species had higher $\mathrm{N}$ use efficiencies at low cellular N:C ratios, while the r-selected species had higher efficiencies at high $\mathrm{N}$ : $\mathrm{C}$ ratios (and associated higher growth rates), further supports the idea that the 2 groups are low- and high-nutrient adapted species, respectively.

\section{DISCUSSION}

\section{Absolute vs. net uptake rates}

In half of our cultures, net and absolute uptake rates were equal, but net rates were only 50 to $90 \%$ of the absolute rates in the other half. This discrepancy is most likely caused by the release of dissolved organic nitrogen (DON) from the cells due to leakage across the cell membrane or intentional release of specific functional solutes (Bronk et al. 1994). The discrepancy between absolute and net rates appears to be related to phylogeny, cell size, and the degree of N-limitation stress. The discrepancy was most pronounced in the coccolithophores (Pleurochrysis carterae and Emiliania huxleyi) and the cryptophyte Rhodomonas salina, where net uptake rates were 20 to $50 \%$ lower than absolute rates. In a previous study with one of the E. huxleyi strains examined here (CCMP 373), 40 to $60 \%$ of assimilated nitrate was subsequently released as DON (Suratman et al. 2008), which is consistent with the present findings. This same strain has been shown to release a number of sulfur-containing amino acids and small peptides that chelate trace metals in the extracellular medium, but the peptides may have other unknown functions (Dupont et al. 2004).

In contrast to most smaller cells, 4 of the 5 largest species (the diatoms Thalassiosira weissflogii and $C y$ - 
clotella cryptica and the 2 dinoflagellates; 10 to $12 \mu \mathrm{m}$ diameter) showed no difference between absolute and net uptake rates under mild to moderate N-limitation, indicating no apparent net release of DON (Table 2). This lack of measurable DON release by these larger cells may be linked to their low surface to volume ratios and thick surface diffusive boundary layers, which limits their ammonium uptake rates (see next subsection), as well as net leakage of $\mathrm{N}$-containing solutes across the outer cell membrane (Raven 1999). This effect could explain why differences in net ammonium uptake rates between small and large cells are less than differences in absolute uptake rates (Table 2 , Figs. 3 \& 4).

A final factor influencing the differences between absolute and net uptake rates is the severity of N-limitation. For both Thalassiosira weissflogii and T. pseudonana, net and absolute uptake rates were equal under mild or moderate N-limitation, but deviated increasingly with increasing severity of N-limitation (Fig. 2). This effect, which was larger for the small diatom, may again reflect leakage of organic solutes from the cells, which may worsen with restricted synthesis of structural proteins, particularly membrane proteins, in severely $\mathrm{N}$-depleted cells. Also, some of the severely $\mathrm{N}$-limited cells may have undergone cell lysis owing to apoptosis or necrosis (Franklin et al. 2006), which would cause an aggregate loss of cellular $\mathrm{N}$ in the cultures. Irrespective of the mechanism, an increasing loss of cellular $\mathrm{N}$ with increasing $\mathrm{N}$-limitation may cause net uptake (and resulting growth) to cease at some finite low ammonium concentration, a phenomenon that was discussed in a previous paper (Sunda et al. 2009).

\section{Diffusion limitation, cell size and grazing susceptibility}

Nutrient uptake by phytoplankton involves 2 sequential steps: molecular diffusion through the unstirred aqueous layer surrounding the cell, and subsequent intracellular transport by cell membrane proteins. It has previously been proposed that algal uptake rates may be limited by nutrient diffusion to the cell surface based on theoretical considerations (Munk \& Riley 1952, Thingstad \& Sakshaug 1990, Kiørboe 1993), but there have been few experimental data to test this hypothesis. Diffusive flux per unit of cell volume increases with the inverse square of the cell diameter (Eq. 3); thus, diffusion limitation should be most acute for larger cells. Our data confirm these predictions (Table 2). Uptake rates for the 5 larger species (10 to $12 \mu \mathrm{m}$ diameter) were on average $70.4 \pm 5.3 \%( \pm \mathrm{SD})$ of the limiting maximum diffusion rate (at which sur- face ammonium concentration is reduced to 0), while mean uptake rates for the 7 smallest isolates $(2.7$ to $4.7 \mu \mathrm{m}$ diameter) were only $28.4 \pm 14.2 \%$ of the maximum diffusion rate. The large SD reflects the fact that the uptake rate of the 4 well defended, K-selected species was only $18.0 \pm 4.4 \%$ of the maximum diffusion rate, while that for Thalassiosira pseudonana and the 2 coastal Emiliania huxleyi clones (370 and 374) was a much higher percentage $(42.3 \pm 8.0 \%)$ of the maximum diffusion rate.

For Thalassiosira pseudonana, the uptake rate (expressed as a percentage of the maximum diffusion rate) increased with decreasing ammonium concentration and increasing $\mathrm{N}$-limitation of growth rate (Table 2). It increased from $36.6 \pm 2.4 \%$ at an ammonium-limited growth rate of $1.29 \mathrm{~d}^{-1}$ (89\% of the nutrient-sufficient maximum growth rate) to $68.1 \pm 13.3 \%$ at a limited growth rate of $0.33 \mathrm{~d}^{-1}(23 \%$ of the maximum rate). Diffusion is proportional to the ammonium concentration, and the increase in the uptake relative to diffusion may reflect an increase in the maximum ammonium uptake rate $\left(V_{\max }\right)$ of the transport system with increasing N-limitation of growth rate, as observed previously with $T$. pseudonana and other algal species (Goldman \& Glibert 1982). It may also reflect decreasing saturation of the transport system with decreasing ammonium concentration, as discussed by Pasciak \& Gavis (1974).

The mean uptake rate as a percentage of the maximum diffusion rate for the 5 largest species $(70 \pm 5 \%)$ falls in the middle of the theoretical maximum range ( 60 to $80 \%$ of the limiting maximum diffusive flux) based on cellular costs and the law of diminishing returns (Hudson \& Morel 1993). As noted earlier, the uptake rate $(V)$ is dependent on the nutrient concentration at the cell surface $\left(C_{\mathrm{S}}\right)$, and as $V$ approaches the maximum diffusion rate $\left(\rho_{\max }\right)$, the nutrient concentration at the surface decreases relative to that in the bulk solution $\left(C_{\mathrm{B}}\right)$ according to Eq. (5), which we show again here in a generalized form:

$$
C_{\mathrm{S}}=C_{\mathrm{B}}\left(1-V / \rho_{\max }\right)
$$

Based on this equation, a cell transporting ammonium at $70 \%$ of the maximum diffusion rate would have its surface concentration decreased to $30 \%$ of that in the bulk seawater, which would greatly restrict its ability to take up ammonium at low, growth-limiting $\mathrm{NH}_{4}{ }^{+}$ levels. However, if the cell were to increase its uptake rate to $90 \%$ of the limiting diffusion rate (a $29 \%$ increase), the surface $\mathrm{NH}_{4}{ }^{+}$would decrease 3 -fold to $10 \%$ of that in the bulk medium. Thus, the cell would incur a very large cost in terms of a much lower surface substrate concentration for only a minimal increase in $\mathrm{N}$ uptake rate. At some point (estimated at 60 to $80 \%$ of the maximum diffusion rate; Hudson \& Morel 1993), the 
increase in benefit to the cell from a slightly higher rate of $\mathrm{N}$ acquisition is outweighed by the high cost of (1) synthesizing additional membrane transport proteins to compensate for the low surface $\mathrm{NH}_{4}{ }^{+}$concentration, (2) allocating additional membrane space for these proteins, and (3) producing more energy (e.g. ATP) to pump ammonium into the cell against an ever increasing concentration gradient between the cell surface and interior. Thus, N-limited transport rates for the 5 larger species ( $\leq 10 \mu \mathrm{m}$ diameter) and for Thalassiosira pseudonana under severe N-limitation (4.3 $\mu \mathrm{m}$ diameter) appear to have evolved to the practical physical diffusion limit. Once this limit is reached, the cellular uptake rate is solely determined by cell size and shape and the ammonium concentration in the bulk medium.

Because limiting diffusion rates per unit of cell volume decrease with the inverse square of the cell diameter (Eq. 3), growth-limiting nutrient concentrations greatly favor the population growth of small-celled algae. Consequently, N-limited ocean systems in the Atlantic and Pacific are all populated by very small algal species, with $\geq 70$ to $80 \%$ of the chl a being found in cells $<2$ to $3 \mu \mathrm{m}$ in diameter (Dickson \& Wheeler 1993, Pérez et al. 2005, Moore et al. 2008). However, the benefit of increased nutrient uptake rates to small cells comes at the cost of efficient grazing by protozoans and other microzooplankton, whose specific reproduction rates can match or exceed those of the phytoplankton (Thingstad \& Sakshaug 1990, Kiørboe 1993). Thus, although a decreased cell size can greatly increase a species' rate of nutrient acquisition and cell division under nutrient limiting conditions, this benefit is offset by higher grazing mortality rates, and also by possible leakage of cell solutes across the outer cell membrane and decreased capabilities for cell motility (Raven 1999). Consequently, the net gain to population growth may be minimal. Thus, there are fundamental evolutionary tradeoffs for the effect of cell size on a species' reproduction and mortality rates, and there may be no single optimal cell size.

\section{Evidence for evolutionary tradeoffs between nutrient assimilation and grazing defense}

Besides the prevalence of diffusive flux limitation of uptake in all the 'well grazed' species or isolates, including smaller ones such as Thalassiosira pseudonana and the coastal strains of Emiliania huxleyi (CCMP 370 and 374), a second intriguing feature of our data was the fact that all of these cells showed essentially the same relationship between ammonium uptake rate per unit of cell surface area and the computed surface ammonium concentration, independent of cell size or phylogeny (Fig. 5). This result agrees with earlier findings with the micronutrient iron, in which the relationship between the cellular iron uptake rate per unit of cell surface and the surface concentration of biologically available dissolved inorganic iron species was the same for 5 species of coastal and oceanic diatoms and dinoflagellates ranging in cell diameter from 4 to $32 \mu \mathrm{m}$ (Sunda \& Huntsman 1997, Sunda 2001). Three of these 5 species (the coastal diatoms T. pseudonana and T. weissflogii and the dinoflagellate Prorocentrum minimum) were also examined in the present experiments. The similarity in iron uptake rates per unit of cell surface between coastal species and highly iron-stressed oceanic species, and between small and large algal species, confirms earlier theoretical predictions (Hudson \& Morel 1993), which state that competition among species should drive uptake rates for important growth-limiting nutrients to the limits permitted by diffusion, chemical kinetics, and geometry. Clearly, this is the case for ammonium with respect to diffusive flux to the cell surface. Moreover, our data suggests that it also applies to ammonium uptake across the outer cell membrane, which is ultimately limited by the area occupied by a single membrane transport protein, the physical space on the membrane, and reaction kinetics between ammonium ions and the transport proteins (Hudson \& Morel 1993).

The above results and theoretical arguments present a paradox: if evolutionary competition drives algal uptake systems for important limiting nutrients to their physical and chemical limits, then why is the uptake rate per unit of cell surface so much lower for the 4 poorly grazed and poorly defended, K-selected algal species and strains? To help solve this paradox, we turn to ecological theory for another major group of phototrophs: terrestrial plants. Because terrestrial plants form the basis of our food supply, are ever present in our environment, and are far easier to observe than microscopic marine algae, their ecology and physiology have received considerably more research attention. As a result, the evolutionary theory for terrestrial plants is much better developed than that for microalgae. However, both groups are subject to the same evolutionary forces of natural selection in terms of resource acquisition and grazing avoidance (Eqs. 1 $\& 2$ ); consequently, much of the evolutionary theory for terrestrial plants should also apply to microalgae.

As noted in 'Results', all phototrophs can be roughly divided into low-resource (K-selected) and highresource adapted (r-selected) species (Kilham \& Hecky 1988, Sommer 1989). K-selected terrestrial plant species generally have low growth rates under resource sufficiency, and surprisingly, also under resource limitation, compared to r-selected species (Lambers et al. 1998). This counter-intuitive result appears to be 
linked to evolutionary tradeoffs between grazing defense and rates of resource acquisition and growth (Coley et al. 1985, Herms \& Mattson 1992, Lambers et al. 1998, Strauss et al. 2002). Because these K-selected species evolved in low-resource environments where growth rates are restricted, they cannot afford high rates of grazing losses. Consequently, to minimize these losses, they typically employ robust grazing defense mechanisms consisting of toxins, anti-digestion compounds (tannins), and physical defenses such as thick cuticles, random cross-linked structures (lignins), and thorns. These robust defense systems incur a high metabolic cost in terms of fixed carbon and limiting nutrients (e.g. N), and plant resources spent on defense are not available to support growth and reproduction. These fundamental tradeoffs between defense and growth are widespread in terrestrial plants, and are thought to explain why lownutrient adapted plant species are typically unable to outgrow r-selected species, even at low nutrient levels (Lambers et al. 1998, Strauss et al. 2002). This is the same pattern that we observed for the $4 \mathrm{~K}$-selected, well defended algal species and strains (Fig. 1), and we argue that similar tradeoffs between grazing defense and resource acquisition and growth explain the similar patterns in both groups of phototrophs.

Like terrestrial plants, algal cells employ a number of grazing defense mechanisms, such as thick cell walls (van Donk et al. 1997, Hamm \& Smetacek 2007), external polymer sheaths (Porter 1973, Liu \& Buskey 2000), and production of toxins or compounds that interfere with digestive processes (Cembella 2003, Sunda et al. 2006). The deployment of these defenses inherently incurs some metabolic cost, but such costs have not been examined by plankton physiologists and ecologists. Such defense mechanisms appear to have helped the 4 K-selected, well defended algal species and strains we examined here to survive evolutionarily despite their poor nutrient uptake kinetics and associated poor rates of growth and reproduction, and in many cases, have allowed them to form robust algal blooms (Sunda et al. 2006). We note, however, that the poor ammonium uptake rates of the 4 well defended algal species are somewhat offset under severe $\mathrm{N}$-limitation of growth rate by higher $\mathrm{N}$ use efficiencies (Fig. 6), but this greater efficiency is insufficient to yield higher growth rates compared to other similarly sized algae (Fig. 1B).

The first of the 4 putative well defended algae, the brown tide species Aureoumbra lagunensis, formed a large continuous algal bloom in the Laguna Madre, Texas from 1990 to 1997, which was associated with low grazing rates by microzooplankton, mesozooplankton, and benthic filter feeders (Buskey \& Stockwell 1993, Buskey \& Hyatt 1995, Buskey et al. 2001).
The species possesses a thick polysaccharide sheath, which appears to deter algal grazers by fouling the cilia that generate feeding currents (Liu \& Buskey 2000) and by allowing the cells to resist digestion in the guts of zooplankton (Bersano et al. 2002). Total carbohydrates account for $55 \pm 12 \%$ (on average) of cellular carbon in A. lagunensis cells grown in ammonium-limited chemostats, and most of this appears to occur in the acidic polysacharride sheath surrounding the cell (Liu \& Buskey 2003). Thus, the production of this protective sheath represents a large direct carbon cost to the cell (not to mention the enzymatic protein costs for its biosynthesis), which limits the available carbon to support nutrient uptake and growth.

Two other well defended species, Nannochloropsis gaditana and Nannochloris atomus, formed large green tide blooms in the shallow bays of southern Long Island, New York in the 1950s, that were associated with the collapse of the oyster industry in that region (Ryther 1989). N. gaditana was observed to be toxic to oyster and clam larvae although the toxin was not identified (Davis \& Guillard 1958). This species contains large amounts of long-chain alcohols, hydroxyketones, and sterols (Méjanelle et al. 2003), and like most secondary metabolites (Lambers et al. 1998), these compounds could be involved in toxicity and grazing defense. The other green tide species, Nannochloris atomus, is well grazed by juvenile clams and oysters, but was reported to be poorly assimilated, and supported little or no growth of these organisms (Bass et al. 1990, Robert 1998). The basis of the poor digestibility and assimilation is unknown, although similar effects are widely seen in terrestrial plants, and are related to the presence of secondary metabolites such as tannins (Lambers et al. 1998).

The final well defended alga, the oceanic isolate Emiliania huxleyi (CCMP 373), is poorly grazed or actively avoided by a variety of protozoan grazers, compared to the 2 coastal strains that we tested (E. huxleyi, CCMP 370 and 374) (Wolfe et al. 1997, Strom et al. 2003). The grazer avoidance and low grazing rates of the oceanic isolate appear to be related to a grazer-activated chemical defense system consisting of high cellular levels of the osmolyte and antioxidant dimethylsulfoniopropionate (DMSP) and the enzyme DMSP lyase, which catalyzes the cleavage of DMSP into acrylic acid (a microbial inhibitor) and DMS (dimethylsulfide, a potential signaling molecule) in cells that are damaged during grazing (Wolfe et al. 1997). The poorly grazed E. huxleyi strain (CCMP 373) had $>1000 \times$ higher cellular activity of DMSP lyase than the well-grazed coastal strains (CCMP 370 and 374) (Wolfe et al. 1997). The molecular nature of this grazeractivated defense system and the metabolic cost of its synthesis are currently unknown. 
There were 3 other putative K-selected isolates (Emiliania huxleyi, CCMP 370 and 374, and Amphidinium carterae) with low $\mathrm{NH}_{4}{ }^{+}$requirements for maximum growth rate (30 to $40 \mathrm{nM}$ ), and which are not known to be poorly grazed. All 3 exhibit relationships between uptake rate per unit of cell surface and surface ammonium concentration that are similar to those of the 4 r-selected species (Fig. 5). The 2 coastal strains of E. huxleyi (370 and 374), have high cellular $\mathrm{N}$ use efficiencies (Fig. 6), which compensates for their somewhat lower net ammonium uptake rates (Fig. 4B). Thus, there may be a wide range of evolutionary survival strategies for low-nutrient adapted algal species in terms of cellular investment in nutrient uptake, growth, and grazing defense.

\section{Evolutionary tradeoffs and genetic diversity}

Overall, our data indicate evolutionary tradeoffs among cell size, nutrient uptake and growth, and grazing susceptibility in marine phytoplankton and provide evidence for tradeoffs between growth and grazing defenses in similarly sized algal species. As in terrestrial ecology, such tradeoffs are fundamentally linked to limitations imposed by geometry, physics, chemistry, and resource allocation within organisms (Tilman 1990). Because of such tradeoffs, there may be no single best survival strategy in terms of size, obtainable rates of net resource (i.e. nutrient) acquisition and growth, and grazing deterrence mechanisms and expense; and many different combinations of these attributes could lead to equal survival rates among species. This equality could in turn allow many species with different competitive strategies to coexist. Such complex interactions may help answer the classic 'paradox of the plankton', which posits why there are so many co-existing algal species in planktonic communities when there are so few apparent ecological niches based on resource competition (Hutchinson 1961). This paradox is based on equilibrium competitive exclusion theory, and thus one explanation is that natural systems are heterogeneous in time and space and rarely reach equilibrium (Levins 1979, Powell \& Richardson 1985). However, we suggest that an additional explanation is that there are many more niches than initially imagined, partly owing to the complex tradeoffs among the critical strategies that species use to optimize reproduction and survival. Such evolutionary tradeoffs should promote species diversity within algal communities, which in turn supports ecosystem stability (Tilman 2000). They also allow the coexistence of species strains with slightly different evolutionary strategies (as observed here in Emiliania huxleyi), and thus should also promote intraspecific genetic diver- sity, and the ability of populations to survive and adapt to environmental challenges. Such intraspecific and interspecific diversity are likely to be critical factors in the response of algal communities to climate change, eutrophication, and other current and future anthropogenic stresses.

Acknowledgements. We thank E. Davenport for help with nonlinear regression analyses and W. Litaker, K. Shertzer, and R. Waggett for critical comments on the manuscript.

\section{LITERATURE CITED}

Bass AE, Malouf RE, Shumway SE (1990) Growth of northern quahogs (Mercenaria mercenaria (Linnaeus, 1758) fed on picoplankton. J Shellfish Res 9:299-307

Bersano JGF, Buskey EJ, Villareal TA (2002) Viability of the Texas brown tide alga, Aureoumbra lagunensis, in fecal pellets of the copepod Acartia tonsa. Plankton Biol Ecol 49: 88-92

$>$ Bronk DA, Glibert PM, Ward BB (1994) Nitrogen uptake, dissolved organic nitrogen release, and new production. Science 265:1843-1846

Buskey EJ, Hyatt CJ (1995) Effects of the Texas (USA) 'brown tide' alga on planktonic grazers. Mar Ecol Prog Ser 126: 285-292

Buskey EJ, Stockwell DA (1993) Effects of a persistent 'brown tide' on zooplankton populations in the Laguna Madre of south Texas. In: Smayda TJ, Shimizu Y (eds) Toxic phytoplankton blooms in the sea. Elsevier, Amsterdam, p 659-666

> Buskey EJ, Liu HB, Collumb C, Bersano JGF (2001) The decline and recovery of a persistent Texas brown tide algal bloom in the Laguna Madre (Texas, USA). Estuaries 24:337-346

Calbet A, Landry MR (2004) Phytoplankton growth, microzooplankton grazing, and carbon cycling in marine systems. Limnol Oceanogr 49:51-57

Cembella AD (2003) Chemical ecology of eukaryotic microalgae in marine ecosystems. Phycologia 42:420-447

Charlson RJ, Lovelock JE, Andreae MO, Warren SG (1987) Oceanic phytoplankton, atmospheric sulfur, cloud albedo and climate. Nature 326:655-661

Cloern JE (2001) Our evolving conceptual model of the coastal eutrophication problem. Mar Ecol Prog Ser 210: 223-253

Coley PD, Bryant JP, Chapin FS (1985) Resource availability and plant antiherbivore defense. Science 230:895-899

Davis HC, Guillard RRL (1958) Relative value of ten genera of microorganisms as food for oyster and clam larvae. Fish Bull US Fish Wildl Serv 58:293-304

Dickson M, Wheeler PA (1993) Chlorophyll a concentrations in the North Pacific: Does a latitudinal gradient exist? Limnol Oceanogr 38:1813-1818

> Droop MR (1968) Vitamin $B_{12}$ and marine ecology. IV. The kinetics of growth and inhibition in Monochrysis lutheri. J Mar Biol Assoc UK 48:689-733

Dupont CL, Nelson RK, Bashir S, Moffett JW (2004) Novel copper-binding and nitrogen-rich thiols produced and exuded by Emiliania huxleyi. Limnol Oceanogr 49: 1754-1762

Dymond J, Lyle M (1985) Flux comparisons between sediments and sediment traps in the eastern tropical Pacific: implications for atmospheric $\mathrm{CO}_{2}$ variations during the Pleistocene. Limnol Oceanogr 30:699-712 
Franklin DJ, Brussaard CPD, Berges JA (2006) What is the role and nature of programmed cell death in phytoplankton ecology? Eur J Phycol 41:1-14

Fung IY, Meyn SK, Tegen I, Doney SC, John JG, Bishop JKB (2000) Iron supply and demand in the upper ocean. Global Biogeochem Cycles 14:281-295

Goldman JC, Glibert PM (1982) Comparative rapid ammonium uptake by four species of marine phytoplankton. Limnol Oceanogr 27:814-827

Hamm C, Smetacek V (2007) Amor: Why, when, and how. In: Falkowski PG, Knoll AH (eds) Evolution of primary producers in the sea. Elsevier, Amsterdam, p 311-332

Harrison WG, Harris LR, Irwin BD (1996) The kinetics of nitrogen utilization in the oceanic mixed layer: nitrate and ammonium interactions at nanomolar concentrations. Limnol Oceanogr 41:16-32

Herms DA, Mattson WJ (1992) The dilemma of plants: to grow or defend. Q Rev Biol 67:283-333

Hudson RJM, Morel FMM (1993) Trace metal transport by marine microorganisms: implications of metal coordination kinetics. Deep-Sea Res 40:129-150

Hutchinson GE (1961) The paradox of the plankton. Am Nat 95:137-147

Keller MD, Bellows WK, Guillard RRL (1989) Dimethyl sulfide production in marine phytoplankton. In: Saltzman ES, Cooper WJ (eds) Biogenic sulfur in the environment, American Chemical Society, Washington, DC, p 167-182

Kilham P, Hecky RE (1988) Comparative ecology of marine and freshwater phytoplankton. Limnol Oceanogr 33: 776-795

Kiørboe T (1993) Turbulence, phytoplankton cell size, and the structure of pelagic food webs. Adv Mar Biol 29:1-72

Lambers H, Chapin FS, Pons TL (1998) Plant physiological ecology. Springer Verlag, New York

Levins R (1979) Coexistence in a variable environment. Am Nat 114:765-783

Liu HB, Buskey EJ (2000) The exopolymer secretions (EPS) layer surrounding Aureoumbra lagunensis cells affects growth, grazing, and behavior of Protozoa. Limnol Oceanogr 45:1187-1191

Liu HB, Buskey EJ (2003) Effects of media N:P ratio on extracellular polymeric substances (EPS) production of the brown tide-forming alga, Aureoumbra lagunensis. Plankton Biol Ecol 50:55-60

Martin JH, Fitzwater SE (1988) Iron deficiency limits phytoplankton growth in the northeast Pacific subarctic. Nature 331:341-343

> Méjanelle L, Sanchez-Gargallo A, Bentaleb I, Grimalt J (2003) Long chain n-alkyl diols, hydroxy ketones and sterols in a marine eustigmatophyte, Nannochoropsis gaditana, and in Brachionus plicatilis feeding on the algae. Org Geochem 34:527-538

Moore CM, Mills MM, Langlois R, Milne A, Achterberg EP, La Roche J, Geider RJ (2008) Relative influence of nitrogen and phosphorus availability on phytoplankton physiology and productivity in the oligotrophic subtropical North Atlantic Ocean. Limnol Oceanogr 53:291-305

Munk WH, Riley GA (1952) Absorption of nutrients by aquatic plants. J Mar Res 11:216-239

Pasciak WJ, Gavis J (1974) Transport limitation of nutrient uptake in phytoplankton. Limnol Oceanogr 19:881-888

> Pérez V, Fernández E, Marañón E, Serret P and others (2005) Latitudinal distribution of microbial plankton abundance, production, and respiration in the Equatorial Atlantic in autumn 2000. Deep-Sea Res I 52:861-880
Porter KG (1973) Selective grazing and differential digestion of algae by zooplankton. Nature 244:179-180

Powell T, Richardson PJ (1985) Temporal variation, spatial heterogeneity, and competition for resources in plankton systems: a theoretical model. Am Nat 125:431-464

Raven JA (1999) Picophytoplankton. Prog Phycol Res 13: 33-106

Robert R (1998) Nutritional inadequacy of Nannochloris atomus and Stichococcus bacillaris for the oyster Crassostrea gigas (Thunberg) larvae. Haliotis 27:29-34

Ryther JH (1989) Historical perspective of phytoplankton blooms on Long Island and the green tides of the 1950s. In: Cosper E, Bricelj VM, Carpenter EJ (eds) Novel phytoplankton blooms. Springer Verlag, Berlin, p 375-381

Ryther JH, Dunstan WM (1971) Nitrogen, phosphorus, and eutrophication in the coastal marine environment. Science 171:1008-1013

Sommer U (1989) The role of competition for resources in phytoplankton succession. In: Sommer U (ed) Plankton ecology. Springer Verlag, Berlin, p 57-106

> Strauss SY, Rudgers JA, Lau JA, Irwin RE (2002) Direct and ecological costs of resistance to herbivory. Trends Ecol Evol 17:278-285

Strom SL (2008) Microbial ecology of ocean biogeochemistry: a community perspective. Science 320:1043-1045

Strom S, Wolfe G, Holmes J, Stecher H, Shimeneck C, Lambert S, Moreno E (2003) Chemical defense in the microplankton. I. feeding and growth rates of heterotrophic protists on the DMS-producing phytoplankter Emiliania huxleyi. Limnol Oceanogr 48:217-229

Sunda WG (2001) Bioavailability and bioaccumulation of iron in seawater. In: Turner DR, Hunter KA (eds) The biogeochemistry of iron in seawater. Wiley, New York, p 41-84

Sunda WG, Hardison DR (2007) Ammonium uptake and growth limitation in marine phytoplankton. Limnol Oceanogr 52:2496-2506

Sunda WG, Huntsman SA (1995a) Iron uptake and growth limitation in oceanic and coastal phytoplankton. Mar Chem 50:189-206

Sunda W, Huntsman S (1997) Interrelated influence of iron, light, and cell size on marine phytoplankton growth. Nature 390:389-392

Sunda WG, Graneli E, Gobler CJ (2006) Positive feedback and the development and persistence of ecosystem disruptive algal blooms. J Phycol 42:963-974

Sunda WG, Shertzer KW, Hardison DR (2009) Ammonium uptake and growth models in marine diatoms: Monod and Droop revisited. Mar Ecol Prog Ser 386:29-41

Suratman S, Weston K, Jickells T, Chance R, Bell T (2008) Dissolved organic matter release by an axenic culture of Emiliania huxleyi. J Mar Biol Assoc UK 88:1343-1346

> Thingstad TF, Sakshaug E (1990) Control of phytoplankton growth in nutrient recycling ecosystems. Theory and terminology. Mar Ecol Prog Ser 63:261-272

> Tilman D (1990) Constraints and tradeoffs: toward a predictive theory of competition and succession. Oikos 58:3-15

- Tilman D (2000) Causes, consequences, and ethics of biodiversity. Nature 405:208-211

van Donk E, Lürling M, Hessen DO, Lokhorst GM (1997) Altered cell wall morphology in nutrient-deficient phytoplankton and its impact on grazers. Limnol Oceanogr 42:357-364

> Wolfe GV, Steinke M, Kirst GO (1997) Grazing-activated chemical defense in a unicellular marine alga. Nature 387 : 894-897

Submitted: June 9, 2009; Accepted: October 26, 2009

Proofs received from author(s): February 12, 2010 